\title{
Height dependence of the tendency for reduction in seasonal snow cover in the Himalaya and the Tibetan Plateau region, 1966-2001
}

\author{
Kunio RIKIISHI, Haruka NAKASATO \\ Department of Earth and Environmental Sciences, Hirosaki University, Hirosaki 036-8561, Japan \\ E-mail: rikiishi@cc.hirosaki-u.ac.jp
}

\begin{abstract}
The dataset of Northern Hemisphere EASE-Grid Weekly Snow Cover and Sea Ice Extent for the period October 1966-July 2001 is analyzed to examine the height dependence of declining tendencies of seasonal snow cover in the Himalaya and the Tibetan Plateau region $\left(25-45^{\circ} \mathrm{N}\right.$, $70-110^{\circ} \mathrm{E}$ ). It is found that the annual mean snow-covered area is decreasing in the Himalaya/Tibet region at a rate of $\sim 1 \% \mathrm{a}^{-1}$, implying that the mean snow-covered area has decreased by one-third from 1966 to 2001 . The rate of decrease is largest $(1.6 \%)$ at the lowest elevations $(0-500 \mathrm{~m})$. On the other hand, the length of the snow-cover season is declining at all elevations, with the greatest rate of decline in the 4000-6000 $\mathrm{m}$ height range. On the Tibetan Plateau ( 4000-6000 $\mathrm{m}$ a.s.l.), the length of the snowcover season has decreased by 23 days, and the end date for snow cover has advanced by 41 days over this 35 year period. These rates might be somewhat overestimated by the binary definition of snow cover on satellite images. It is likely that the reduction of the snow surface albedo by deposition of Asian dust and anthropogenic aerosols may be at least partly responsible for earlier snowmelt.
\end{abstract}

\section{INTRODUCTION}

The Tibetan Plateau occupies a large area $(1000 \mathrm{~km}$ by $2000 \mathrm{~km})$ in the southeastern region of the Eurasian continent. Because of its large area and high elevation ( 4500$5500 \mathrm{~m}$ ), the plateau plays an important role in the climate system as a heat source in summer and a heat sink in winter for the middle troposphere. On the other hand, the Himalaya efficiently capture water vapor contained in the upper troposphere, as precipitation frequently falls as snow in the local area. The seasonal snow cover in the Himalaya/ Tibet region exerts a strong influence on the atmospheric circulation in the Northern Hemisphere through the snowalbedo feedback and snow-hydrological effects (Yasunari and others, 1991). In addition, the seasonal snow cover is very important from the viewpoint of water resources for the people of Southeast Asia, who account for almost one-third of the world's population.

Time changes of termini of the Himalayan glaciers are good indicators of the cryospheric change in the Himalaya/ Tibet region. It has been suggested that in the last 20 years, Himalayan glaciers have retreated more rapidly than glaciers in other parts of the world (Fujita and others, 1997; Kadota and others, 1997; Nakawo 2001). The Himalayan glaciers are unique as they are located in very high mountains in lower latitudes where accumulation occurs mainly in summertime, whereas on glaciers in most other parts of the world it occurs in wintertime. Moreover, the Himalayan glaciers are abundant in biotic communities that conduct photosynthesis (Kohshima, 1984, 1987). Obviously, recent global warming alone may not explain why the large-scale retreat of the Himalayan glaciers has been so fast and extensive. It is now believed that warming of the Earth's globally averaged temperature not only directly accelerates snowmelt in the Himalaya/Tibet region, but also indirectly enhances snowmelt there by reducing the snow surface albedo or by absorbing more solar energy through the following processes (Nakawo, 2001): (1) global-scale warming reduces the occurrence of solid precipitation in summertime, which reduces the surface albedo; and (2) this warming may help biotic communities living in ablation areas to form dusty layers which further reduce the albedo at the glacier surface (Kohshima, 1987; Kohshima and others, 1993; Takeuchi and others, 2001).

Naturally, the snow-cover extent in the Himalaya/Tibet region varies considerably from year to year due to changes in both air temperature and atmospheric circulation. Zhang and Wang (2004) have studied the interdecadal variation of the spring snow depth over the eastern Tibetan Plateau in relation to circulation changes. They have examined the possible relationship between the March-April snow cover over the eastern Tibetan Plateau and the subsequent East Asian summer monsoon.

Our knowledge of the details regarding seasonal snow cover in the Himalaya/Tibet region is quite limited. Recently, Rikiishi and others (2004) studied time variations in the length of a snow-cover season in the Northern Hemisphere and reported that the rate of shortening of the season is increasing in both mid-latitudes and high-elevation regions. The rate of change (negative) is greatest for the Himalaya/ Tibet region, with values generally exceeding -0.2 weeks $\mathrm{a}^{-1}$. For the decline of seasonal snow cover, the contribution from advanced snowmelt is much greater than that from delayed snowfall. These facts suggest that the glaciological environment of the Himalaya/Tibet region has changed rapidly in recent years.

This paper examines whether or not elevation plays an important role in the reduction of seasonal snow cover in the Himalaya/Tibet region. The higher elevations may more strongly reflect global or large-scale changes in atmospheric circulation and the Earth's environment, while the lower elevations may be more sensitive to the direct effects of human activities. For this reason, we focus on both the regional features and the height dependence of snow-cover 
Table 1. Least-squares fittings of the form $F(X)=a X+b$ for the five categories of elevation in the Himalaya/Tibet region (the first row of each cell), where $X$ is the year number starting from 1966, a the trend, and $b$ the expected value of $F(X)$ at $X=0$ (or at the year 1966). The numbers in parentheses in the second row of each cell represent the normalized trends defined as $a / b$

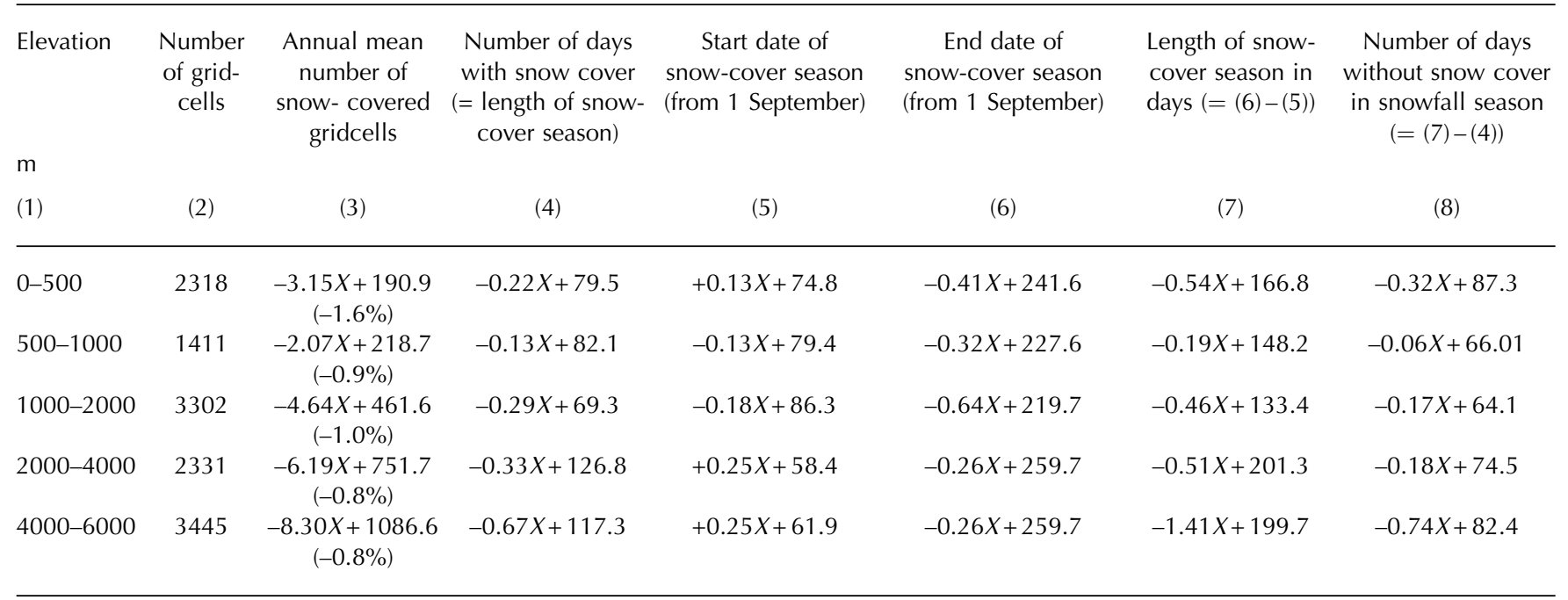

changes to gain better insight into the possible causes of the recent snow-cover decline. The same method of analysis as for the Himalaya/Tibet region will be applied to other regions, namely the Rocky Mountains, the Alps and the Scandinavian peninsula, to interpret the results in a more global context.

\section{DATA AND METHOD OF ANALYSIS}

The dataset used here is of historical satellite observations of weekly snow-cover extent, namely, the Northern Hemisphere EASE-Grid (Equal-Area SSM/I (Special Sensor/Microwave/Imager) Earth Grid) Weekly Snow Cover and Sea-Ice Extent (Version 2) available from the US National Snow and Ice Data Center (NSIDC; Armstrong and Brodzik, 2002). This dataset is compiled from the US National Oceanic and Atmospheric Administration-National Environment Satellite Data and Information Service (NOAA-NESDIS) Weekly Northern Hemisphere Snow Charts $(89 \times 89$ cells $)$ based on visual interpretation of visible imagery by trained meteorologists. The dataset covers the period 3 October 1966 to 24 June 2001, with three breaks from 1 to 28 July 1968 (4 weeks), from 2 June to 26 October 1969 (21 weeks) and from 5 July to 26 September 1971 (12 weeks). Although the nominal resolution of the EASE-Grid is $625 \mathrm{~km}^{2}$ $(25 \mathrm{~km} \times 25 \mathrm{~km})$, the spatial resolution of the original NOAA charts ranges from 16000 to $42000 \mathrm{~km}^{2}$ (Robinson and others, 1993). (The resolution of original cells for the Himalaya/Tibet region will later be shown to be around $18000 \mathrm{~km}^{2}$. Accordingly, a cell on an original NOAA chart is roughly equivalent to 30 cells on an EASE-Grid.) It is noted here that an original cell was regarded as 'snow-covered' when snow covered $>50 \%$ of the cell area. In other words, the land surface is expressed by the digit 1 (snow-covered) or 0 (snow-free). Consequently, scattered snowpacks or patches of snow cover are often neglected through this binary definition.

Individual EASE-Grid cells are divided into five categories according to elevations of 0-500, 500-1000, 1000-2000, 2000-4000 and 4000-6000 m. The elevations are determined at the center of individual EASE-Grid cells by referring to the dataset of GTOPO30 (available from the United States Geological Survey), whose spatial resolution is $30^{\prime \prime} \times 30^{\prime \prime}$. The category for elevation higher than $6000 \mathrm{~m}$ is discarded in this paper, because the total number of EASEGrid cells for this category is found to be only 27. (See Table 1 for total numbers of EASE-Grid cells for individual categories). It is noted here that the snow-cover status (1 or 0 ) for an original cell is shared with about 30 EASE-Grid cells of various elevations (which are generally close to the mean elevation for the original cell). Consequently, the snowcover statuses for individual EASE-Grid cells do not always reflect only those for their own category but are sometimes contaminated by those of other elevation categories. If we take an average over many EASE-Grid cells belonging to an elevation category, however, we obtain a weighted mean snow-cover status, weights being the numbers of EASE-Grid cells for individual elevation categories and maximal at the elevation concerned. For this reason, we can examine the height dependence of the decline of seasonal snow cover in the Himalaya/Tibet region. We will later see in Figure 3 that some information on the Himalayan glaciers is indeed obtained in spite of the original snow chart not being fine enough to resolve individual glaciers.

To begin with, weekly total numbers of snow-covered gridcells are counted for the Himalaya/Tibet region. Note that the numbers can easily be converted to snow-cover area by multiplying by $625 \mathrm{~km}^{2}$. The total number of snowcovered gridcells includes even intermittent snow cover in less snowy regions, and then it gives total information on the snow cover in this region. Annual mean numbers of snowcovered gridcells are also calculated for the five categories in order to examine the height dependence of interannual variations of seasonal snow cover.

In this paper, we define the snow-cover year as starting on 1 September and ending on 31 August. For example, the snow-cover year 1990 represents the period 1 September 1989 to 31 August 1990. For each year, the start (or end) date of the snow-cover season is defined as the middle date of the week when snow cover is observed for the first (or last) time in the season. Then, the length of a snow-cover season is defined as the number of days with snow cover (or number 


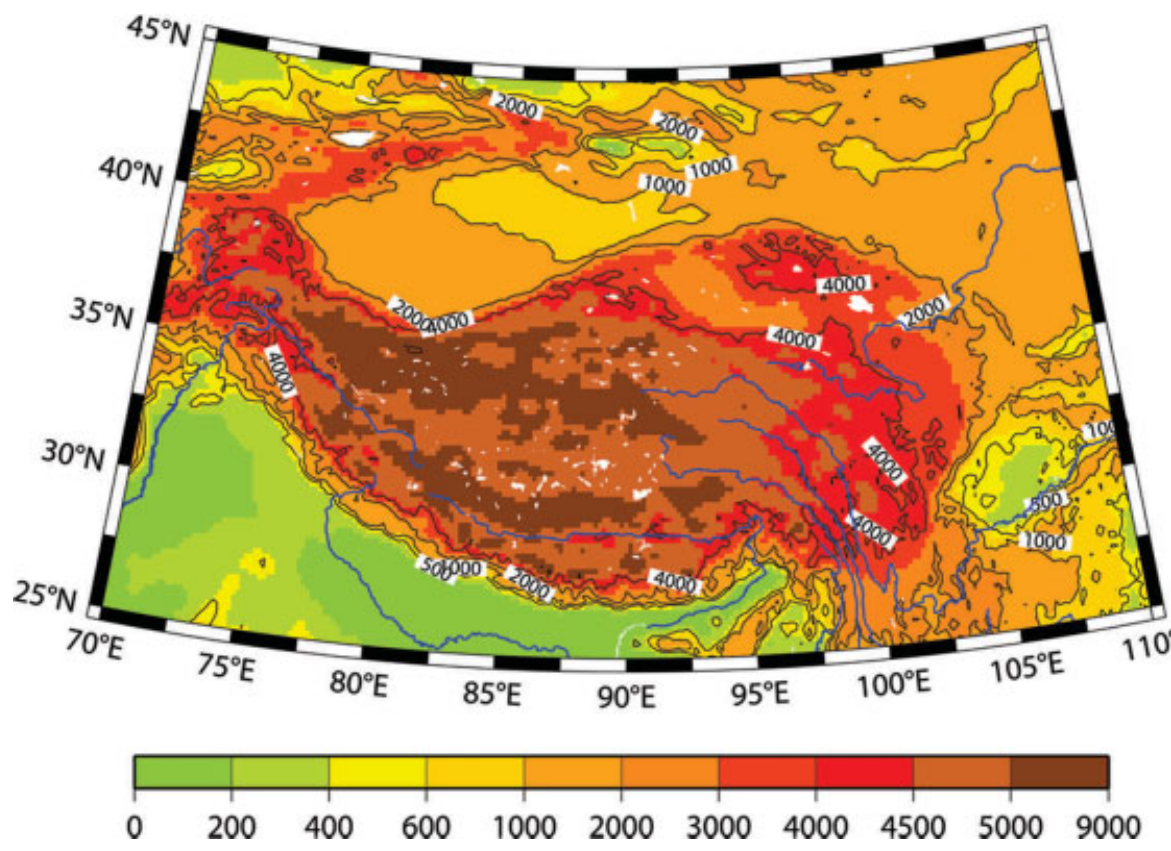

Fig. 1. Topography of the Himalaya/Tibet region, bounded by the parallels $25^{\circ} \mathrm{N}$ and $45^{\circ} \mathrm{N}$ and the meridians $70^{\circ} \mathrm{E}$ and $110^{\circ} \mathrm{E}$. Major rivers, from west to east, the Indus, Ganges, Brahmaputra, Salween, Mekong, Yangtze and Yellow rivers, are shown by heavy solid lines.

of snow-cover days). Note that the length of a snow-cover season is different than the interval between the start and end dates of the snow-cover season. For simplicity, the latter is called the length of a winter season in this paper. Obviously, the difference between the two lengths represents the number of days without snow cover (or number of snow-free days) in a winter season, or a measure of the intermittency of seasonal snow cover.

To examine the decline of seasonal snow cover, linear fitting is applied to the 35 year time series of the annual mean number of snow-covered gridcells, the length of a snow-cover season, and the start and end dates of seasonal snow cover, assuming that linear trends are independent of variations on smaller timescales. The linear fitting is applied not only to the time series of snow cover for the five categories but also to those for individual EASE-Grid cells. In the latter case, we are concerned only with cells showing snow cover for more than 27 seasons out of 35 , in order to assure statistical reliability.

We note here that the above-mentioned three breaks in satellite imagery may have significant effects on the linear trend estimation for higher-elevation regions where snow cover often survives until mid-summer or even throughout the summer.

\section{GENERAL DESCRIPTION OF TOPOGRAPHY AND SEASONAL SNOW COVER}

The Himalaya/Tibet region defined in this study covers the area bounded by the parallels $25^{\circ} \mathrm{N}$ and $45^{\circ} \mathrm{N}$ and the meridians $70^{\circ} \mathrm{E}$ and $110^{\circ} \mathrm{E}$ (Fig. 1). The Himalaya form a high-altitude belt which separates the Tibetan Plateau ( 4500-5500 ma.s.l.) from the Indian subcontinent. To the north of the Tibetan Plateau lie dry and waste lands such as the Taklimakan and Gobi deserts. In summertime, the eastern part of the region is strongly affected by the Indian monsoon which sometimes even brings snowfalls at higher elevations. In wintertime, on the other hand, the Himalaya/Tibet region is controlled by the Siberian High (centered roughly at $45^{\circ} \mathrm{N}$, $90^{\circ} \mathrm{E}$ ), and dry, cold northerly winds suppress snowfalls in the region. It should be emphasized that the snow cover in the Himalaya/Tibet region is the source of water for many major rivers such as, from west to east, the Indus, Ganges, Brahmaputra, Salween, Mekong, Yangtze and Yellow rivers (indicated by heavy solid blue lines in Fig. 1).

The time series of the weekly total number of snowcovered cells is shown in Figure 2. Obviously, the maximum (or peak) values represent those for winter seasons, and the minimum (or trough) values those for summer seasons. In other words, the peak values mainly represent snow covers at lower elevations in wintertime, and the trough values those at higher elevations in summertime. On inspecting the figure, we find that the number of snow-covered cells has a larger variability in wintertime than in summertime. This

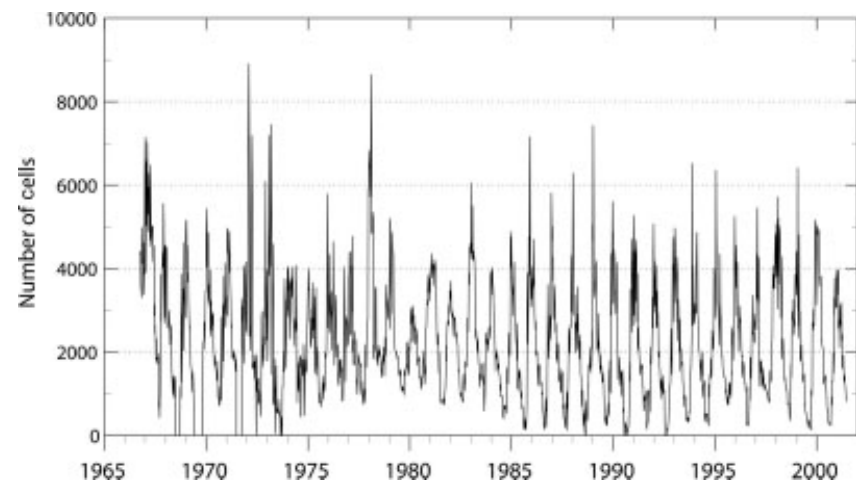

Fig. 2. Time series of the weekly total number of snow-covered cells. The vertical scale can be converted to snow-covered area by multiplying by $625 \mathrm{~km}^{2}$. The data cover the period 3 October 1966 to 24 June 2001, with three breaks from 1 July to 28 July 1968 (4 weeks), 2 June to 26 October 1969 (21 weeks) and 5 July to 26 September 1971 (12 weeks). Note that the peak values correspond to the numbers of snow-covered cells in wintertime, and the trough values to those in summertime. 


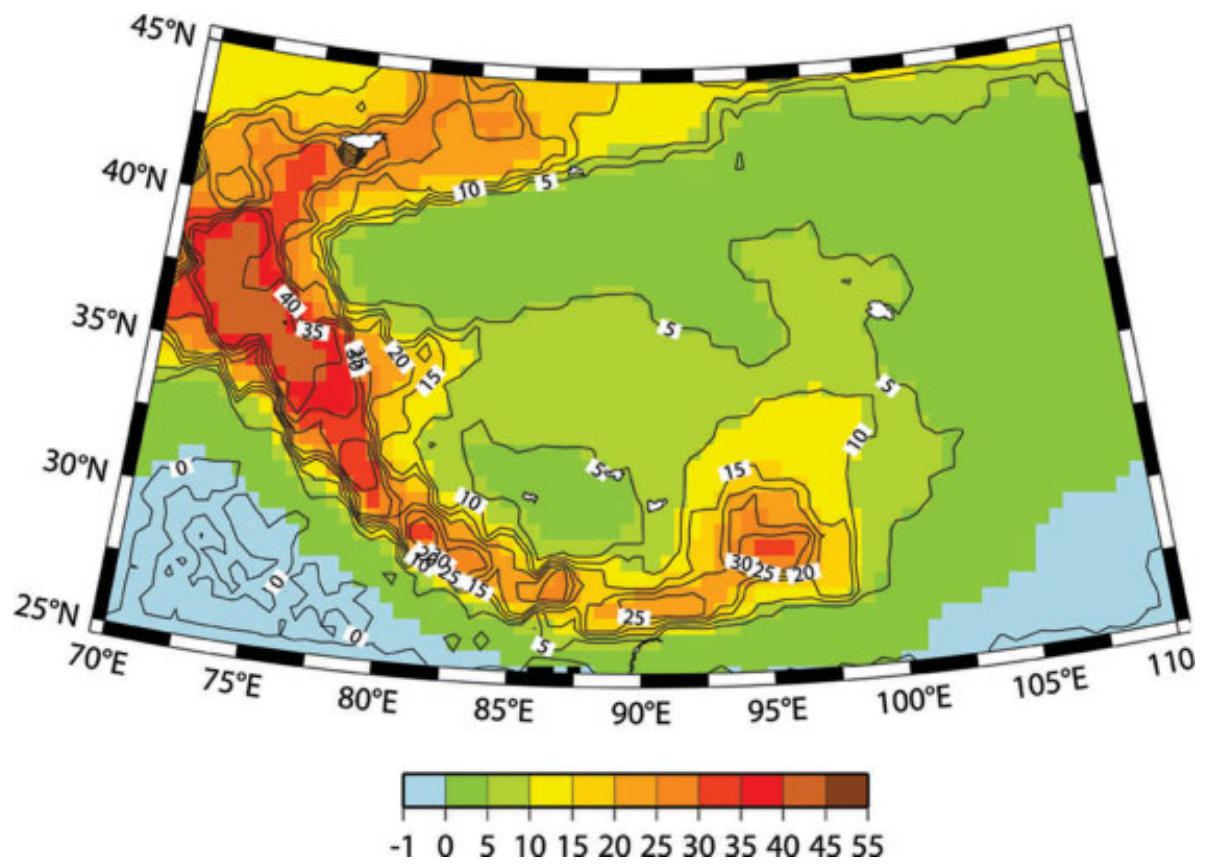

Fig. 3. Geographical distribution of the mean length of a snow-cover season over the 35 years, in weeks.

may simply reflect the fact that the snow cover tends to be more intermittent at lower elevations than at higher elevations. It can be clearly seen that both the peak and trough values are decreasing during the 35 years. The decrease of trough values is quite consistent with the fact that the majority of termini of the Himalayan glaciers have retreated rapidly in recent decades (e.g. Fujita and others, 1997; Kadota and others, 1997; Nakawo, 2001). In the figure, we notice that decadal fluctuations are superimposed on the general trend. For example, the low values are largest during the periods 1975-84 and 1995-99 and smallest during the period 1985-94. Since the decadal fluctuations are not synchronous with recent global warming, it seems unlikely that the two have any relationship.

Figure 3 shows the geographical distribution of the mean length of a snow-cover season in weeks. Clearly, the snowcover season is much longer in the Karakoram ranges and the Himalaya than in surrounding areas, although the lengths are $<50$ weeks ( 47 weeks at most). This indicates

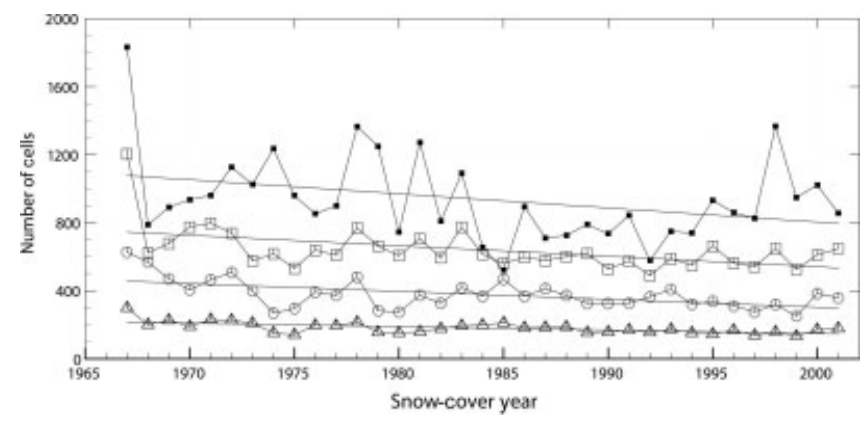

Fig. 4. Time variations of the annual mean number of snow-covered gridcells for the elevations 500-1000 m (open triangles), 1000$2000 \mathrm{~m}$ (open circles), 2000-4000 m (open squares) and 4000$6000 \mathrm{~m}$ (solid squares). The elevations $4000-6000 \mathrm{~m}$ roughly correspond to the Tibetan Plateau. Note that observations are missing for 4, 4, 13, 8, 8 and 4 weeks in snow-cover years 1967, 1968, 1969, 1970, 1971 and 1972, respectively. that some information on the Himalayan glaciers can be obtained by the binary expression for snow cover in the EASE-Grid system. Notice that the snow-cover season is much longer in the Karakoram ranges and the western Himalaya (40-45 weeks) than in the central Himalaya (2025 weeks). This may be partly because the Karakoram ranges and the western Himalaya are located in more northerly latitudes than the central Himalaya by about $10^{\circ}$. In addition, the areas of higher elevation in the central Himalaya are smaller than those of the Karakoram ranges and the western Himalaya, suggesting that glaciers in the central Himalaya are smaller. In other words, the central Himalayan glaciers are likely to be regarded as 'snow-free' in summertime in this study. In the eastern Himalaya near Bhutan, the snow-cover season lasts about 20-30 weeks, slightly longer than in the central Himalaya. This may again be explained by the fact that the eastern Himalaya are located at higher latitudes by about $5^{\circ}$ than the central Himalaya.

To the north of the Himalaya, the snow-cover season is very short, in spite of the very cold winter climate: the snowcover season lasts 5-10 weeks over the majority of the Tibetan Plateau and $<5$ weeks in the Taklimakan and Gobi deserts and northwest China. This may be because the air is very dry and there is no orographic upward draft to bring heavy snowfalls in these regions.

\section{HEIGHT DEPENDENCE OF THE SNOW-COVER DECLINE IN THE HIMALAYA/TIBET REGION}

To visualize the height dependence of the declining tendency of the seasonal snow cover, interannual variations of the annual mean number of snow-covered cells are shown in Figure 4 for the elevation categories 500-1000, $1000-2000,2000-4000$ and $4000-6000 \mathrm{~m}$. The horizontal axis represents the snow-cover year as defined before. In the figure the results of linear fitting of the form $F(X)=a X+b$ are also shown, where $X$ is the year number defined as the 


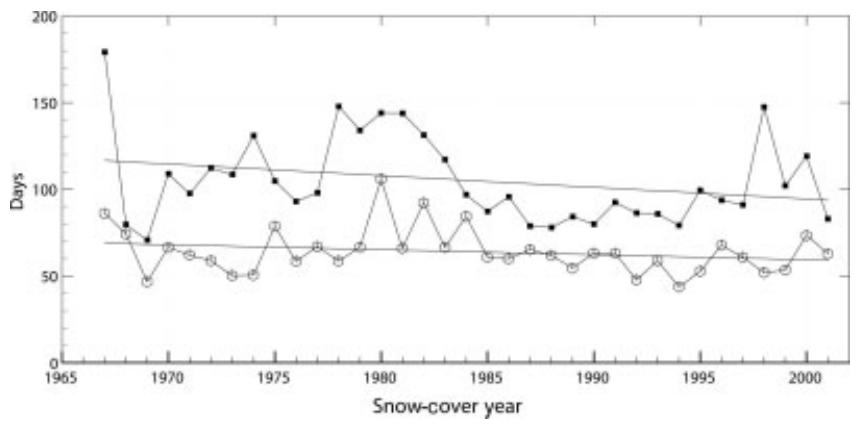

Fig. 5. Time variations of the length of a snow-cover season at the elevations of 1000-2000 m (open circles) and 4000-6000 m (solid squares) in days. Note that observations are missing for 4, 4, 13, 8, 8 and 4 weeks in snow-cover years 1967, 1968, 1969, 1970, 1971 and 1972 , respectively.

snow-cover year minus 1966. (See Table 1 for specific values for $a$ and $b$.) The figure clearly shows a general decline in snow-covered area for all four categories.

At the same time we notice that, while the decline is rather gradual for the categories 500-1000 and 1000$2000 \mathrm{~m}$, the decline for the categories 2000-4000 and 4000-6000 $\mathrm{m}$ appears to be driven by the extraordinarily large values for snow-cover year 1967. We note that the linear trends calculated from the time series of the period 1968-2000 are shown to be still negative and statistically reliable. This kind of peculiarity is not observed either at the lower elevations or in other regions of the world such as the Scandinavian peninsula, the Alps and the Rocky Mountains. Therefore, it is unlikely that the prominent value is erroneously introduced by visual interpretation of satellite images. Instead, it must be introduced by the effect of three breaks in satellite observation in summertime, which may only be discernible at higher elevations. Because the breaks extend over two consecutive years and the satellite observations are unavailable for September 1966, we miss 4, 4, 13, 8, 8 and 4 weeks for the 6 years $1967-72$, respectively. Since all of the potential snow covers for these periods cannot be included in our analysis, it is likely that the number of snowcovered cells is underestimated for the above years (particularly 1969-71). If they could be included, the snow-cover decline at 2000-4000 and 4000-6000 m would be much more reasonable.

On inspecting Figure 2, on the other hand, we find that the number of snow-covered cells was indeed very large throughout snow-cover year 1967. In addition, the number of snow-covered cells at $4000-6000 \mathrm{~m}$ shows a decadal variation, with maxima during the periods 1977-83 and 1995-2000 (Fig. 4). This is quite consistent with decadal fluctuations of the total number of snow-covered cells in summertime (Fig. 2). Accordingly, we may expect that the unusual value for 1967 is part of the decadal variation of summertime snow cover in the Himalaya/Tibet region. If the missing data for the snow-cover years 1967-72 could be provided, then the decadal variation would make a much more moderate curve.

The results of linear fitting are listed in the third column of Table 1 for the five categories. It is clearly seen that the trends are negative at all the elevations. Although the decreasing rate appears to increase with height, this is partly because the estimated values for $a$ and $b$ depend on the total number of EASE-Grid cells for each category (see second

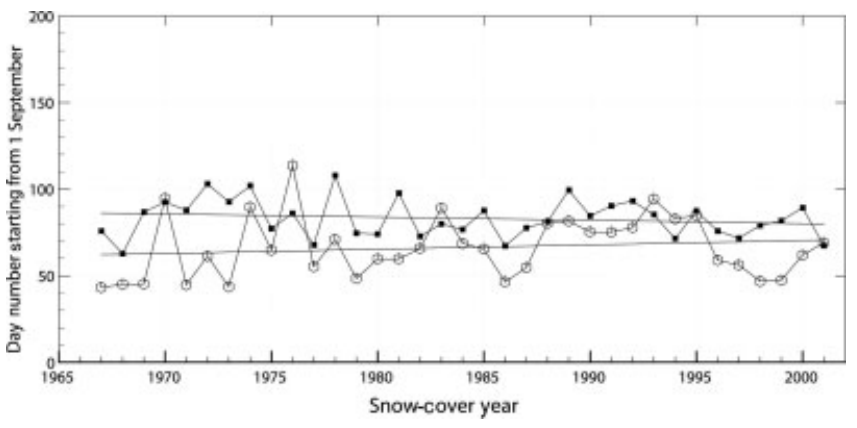

Fig. 6. Time variations of the start date of the snow-cover season for the elevations 1000-2000 m (open circles) and 4000-6000 m (solid squares). The vertical axis denotes the day number starting from 1 September. Note that observations are missing for 4, 8 and 4 weeks in snow-cover years 1967, 1969 and 1971, respectively.

column of Table 1). For the discussion of the snow-cover decline, we should use the normalized linear trend $(a / b$; numbers in parentheses in the second row of each cell in the table) instead of the nominal linear trend (a). According to Table 1, the annual mean number of snow-covered cells is decreasing at a rate of $\sim 1 \% \mathrm{a}^{-1}$, with larger rates at lower elevations. This may lead to the conclusion that the annual mean snow-cover area has decreased by one-third over the period 1967-2001.

Here, we should recall that, in the binary expression of snow cover, the reduction in snow-cover area of a cell from $75 \%$ to $25 \%$ is totally equivalent to that from $100 \%$ to $0 \%$. This implies that we tend to overestimate the decreasing rate of snow cover especially in mountainous regions where snowpacks are patchy and scattered. However, the overestimation may be somewhat reduced because positive and negative errors may partly be averaged out over the observation period of 35 years.

Figure 5 shows time variations of the length of a snowcover season or the number of snow-cover days for elevations of 1000-2000 and 4000-6000 m. Although values for the years $1967-72$ are again underestimated because of the breaks, the number of snow-cover days is clearly decreasing at rates of -0.29 and -0.67 days $^{-1}$ (see fourth column of Table 1). From the negative trends shown in the fourth column, it can be deduced that the snow-cover duration has decreased by 23 days at elevations of 4000 $6000 \mathrm{~m}$ and by 5-11 days at elevations lower than $4000 \mathrm{~m}$. From the values for $b$ in the fourth column, on the other hand, the length of the snow-cover season in 1966 is expected to be $70-80$ days at elevations lower than $2000 \mathrm{~m}$, and nearly 120 days at elevations of $2000-6000 \mathrm{~m}$.

Figure 6 shows time variations of the start date of the snow-cover season for elevations of 1000-2000 and 4000$6000 \mathrm{~m}$. While the start date at elevations of $4000-6000 \mathrm{~m}$ is being delayed at a rate of 0.25 days $\mathrm{a}^{-1}$, that at elevations of $1000-2000 \mathrm{~m}$ is advancing at a rate of -0.18 days $^{-1}$ (see fifth column of Table 1). Even if we had the missing observations for snow-cover years 1967 (4 weeks), 1969 (8 weeks) and 1971 (4 weeks), the trends would not be modified because the snow cover starts later than midOctober in the Himalaya/Tibet region.

Finally, time variations of the end date of the snow-cover season are shown in Figure 7 for elevations of 1000-2000 and $4000-6000 \mathrm{~m}$. The end date is getting earlier at both elevations at a rate of -0.64 and -1.16 days $\mathrm{a}^{-1}$, respectively 


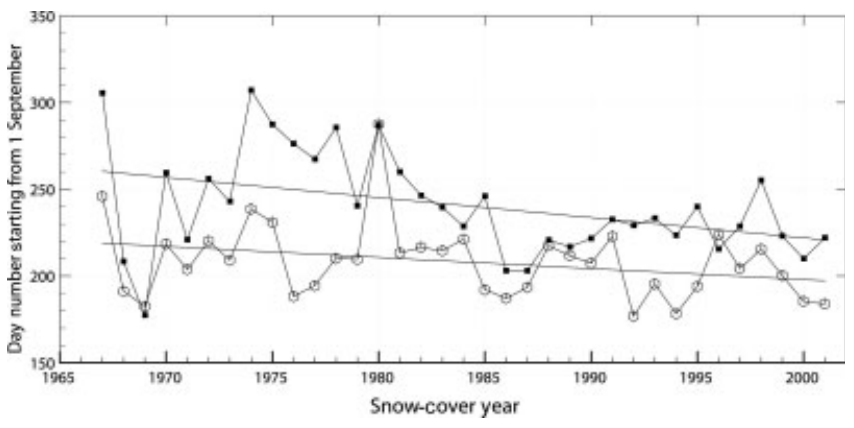

Fig. 7. Time variations of the end date of the snow-cover season for the elevations 1000-2000 m (open circles) and 4000-6000 m (solid squares). The vertical axis denotes the day number starting from 1 September. Note that observations are missing for 4, 13 and 8 weeks in snow-cover years 1968, 1969 and 1971, respectively.

(see sixth column of Table 1). If we had the missing weeks of satellite observation for 1968 (4 weeks), 1969 (13 weeks) and 1971 ( 8 weeks), the negative rates would surely be more significant.

On inspecting linear trends for other elevations in Table 1, we see that the start-date trends are positive at some elevations and negative at others. This may suggest that they are statistically unstable or unreliable. In contrast, the enddate trends are negative for all five categories. This is consistent with the finding of our previous study that snow is melting earlier almost everywhere in the world (Rikiishi and others, 2004). Using the linear trends, we deduce that snow on the Tibetan Plateau has melted away 22 days earlier at the 1000-2000 m elevations, and 40 days earlier at the 4000 $6000 \mathrm{~m}$ elevations. (Recall that the binary expression for snow cover tends to overestimate the rate of snowmelt advance.) Trends for elevations lower than $1000 \mathrm{~m}$ suggest that snow has melted away about 10-15 days earlier over the 35 year period.

The $b$ values of the fifth and sixth columns of Table 1 provide measures of start and end dates of snow cover in 1966. The date is given in terms of the day number starting from 1 September. For example, day numbers 61, 212 and 273 correspond to the ends of October, March and May, respectively. At elevations of $2000-6000 \mathrm{~m}$, snow cover is expected to begin in late October-early November and end in mid-May, implying that snow accumulation occurs in wintertime on the Tibetan Plateau.

The period between the start and end dates of seasonal snow cover (see seventh column of Table 1) is called here the length of the winter season. The difference between the length of the winter season and that of the snow-cover season (eighth column of Table 1) represents the number of days without snow cover (or of snow-free days) in a winter season. At elevations lower than $2000 \mathrm{~m}$, we find that the number of snow-cover days is comparable with that of snow-free days. If we define the intermittency of snow cover as the ratio of the number of snow-free days to the length of the winter season, the intermittency is almost $50 \%$ at the lower elevations. This decreases to about $40 \%$ at elevations of $2000-6000 \mathrm{~m}$. It is likely that the binary expression for snow cover in the Himalaya/Tibet region is partly responsible for these high values of intermittency. From the seventh and eighth columns, we may conclude that the length of the winter season and the number of snow-free days (intermittency) are also decreasing in the Himalaya/Tibet region.

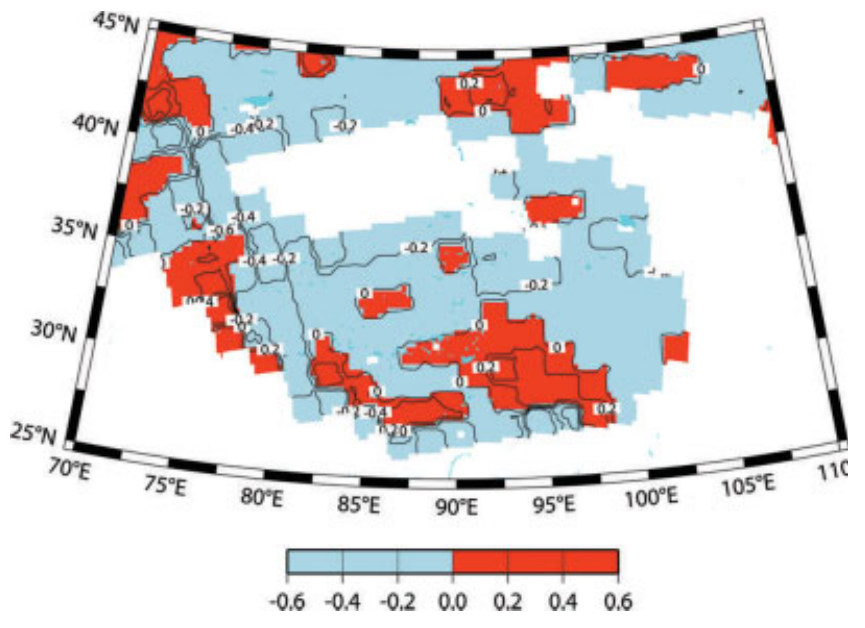

Fig. 8. Geographical distribution of the linear trend of the length of a snow-cover season (or number of weeks with snow cover) in weeks $\mathrm{a}^{-1}$.

We now proceed to examine the linear trends for individual EASE-Grid cells, in order to understand the geographical features of the decline of seasonal snow cover. Figure 8 shows the geographical distribution of linear trends for the length of a snow-cover season. Note that the trends are given in units of weeks $\mathrm{a}^{-1}$ instead of days $\mathrm{a}^{-1}$, because the trends for individual cells are an order of magnitude higher than those for the five elevation categories (fourth column in Table 1). The length of a snow-cover season is generally decreasing at rates of $0.2-0.4$ weeks $^{-1}$ in the Karakoram ranges and the western-central Himalaya, and $0.0-0.2$ weeks a $^{-1}$ on the Tibetan Plateau. This is consistent with the result of Table 1 (fourth column), in that the decreasing rate is larger at higher elevations. Remember that we are only concerned with cells that are snow-covered for at least 1 week for 27 years or more. The blank area in Figure 8 indicates that snow cover was observed there for less than 27 of the 35 years. The fact that the blank area corresponds to the area of lower elevations suggests that the spatial resolution of the original snow charts is fine enough to resolve the height dependence of seasonal snow cover.

Positive trends of the length of a snow-cover season are only seen in a limited region in the eastern Himalaya. Zhang and Wang (2004) have shown that the spring snow depths on the eastern Tibetan Plateau have increased over the period 1962-93. These are the areas over which southwesterly winds (monsoons) travel toward China in summertime. Zhao and Moore (2004) have found negative correlation between the snow covers on the western and eastern Tibetan Plateau and discussed their possible relation with changes in the monsoon wind system. Although we have no further evidence, it seems likely that the above positive trends are related to activity of the Indian monsoon.

Geographical distribution of the linear trends for the start and end weeks of the snow-cover season is shown in Figures 9 and 10, respectively. In these cases, we are concerned only with cells that are snow-covered for more than 2 weeks for more than 27 years so that we can determine both the start and end weeks separately. We therefore see more blank cells in Figures 9 and 10 than in Figure 8 . Note that the original NOAA snow charts $(89 \times 89$ gridcells) can be traced on this EASE-Grid system. The startweek trend (Fig. 9) is rather variable in space and does not 


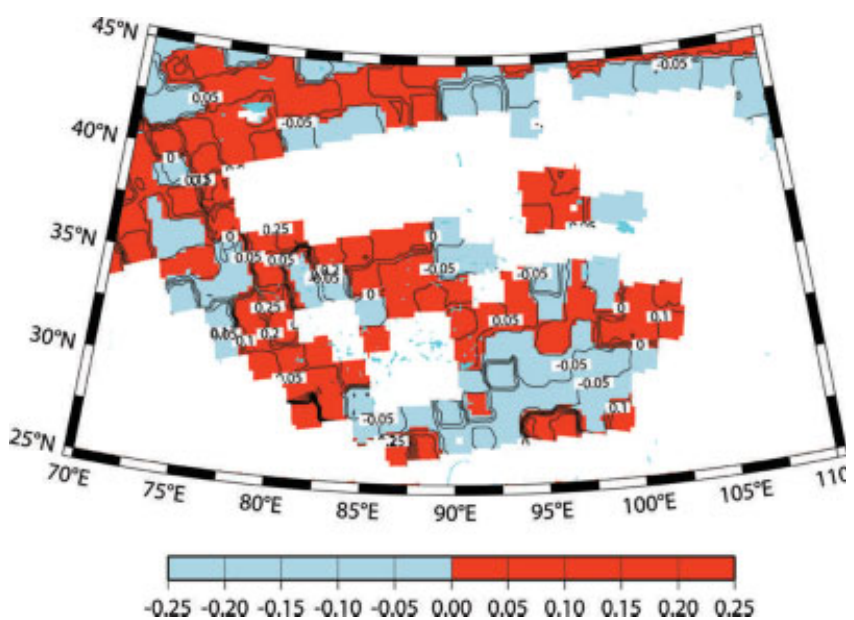

Fig. 9. Geographical distribution of the linear trend of the start week of the snow-cover season in weeks $\mathrm{a}^{-1}$.

show clear regional features. On the other hand, the end week of the snow-cover season (Fig. 10) shows that snow is melting earlier in almost all regions except the eastern Himalaya (around $30^{\circ} \mathrm{N}, 95^{\circ} \mathrm{W}$ ). On inspecting Figure 10, we find a more rapid trend towards earlier snowmelt on the Tibetan Plateau than in the Himalaya. In the Karakoram ranges and the western-central Himalaya, the snow season is starting later and ending earlier. In the eastern Himalaya, however, the opposite is the case: the snow-cover season is getting longer, starting earlier, and ending later. This is quite different from what is expected from the recent global warming.

In general, the regional features of Figure 10 are very similar to those of Figure 8 . This may be another example where the decrease in the length of the snow-cover season can be mostly explained by earlier snowmelt.

\section{DISCUSSION}

Because of its high altitude, the Himalaya/Tibet region is covered with snow in spite of being in relatively low latitudes $\left(25-45^{\circ} \mathrm{N}\right)$. From the point of view of water

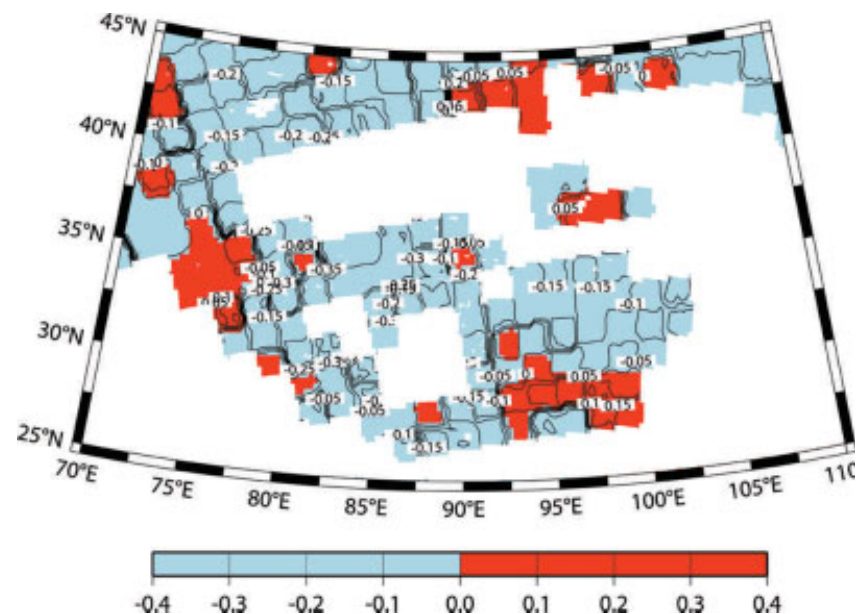

Fig. 10. Geographical distribution of the linear trend of the end week of the snow-cover season in weeks $\mathrm{a}^{-1}$.

resources, it is one of the most important regions of snow cover in the world. The interannual variation of the seasonal snow cover in the Himalaya/Tibet region is therefore of great concern. As has been described above, the annual mean snow-cover area in the region has diminished by one-third over the last 35 years. Moreover, the mean length of the snow-cover season has been reduced by about 25 days, and the end date of the snow-cover season has advanced by 40 days on the Tibetan Plateau. (This does not necessarily mean that the start date of the snow-cover season has advanced by 15 days. See the discussion about Table 1 for details.)

To discuss the snow-cover decline in the global context, the same method of analysis has been applied to other regions: the Rocky Mountains $\left(30-60^{\circ} \mathrm{N}, 100-140^{\circ} \mathrm{E}\right)$, the Alps $\left(25-45^{\circ} \mathrm{N}, 70-110^{\circ} \mathrm{E}\right)$ and the Scandinavian peninsula $\left(56-72^{\circ} \mathrm{N}, 4-30^{\circ} \mathrm{E}\right)$. The results of linear fitting are presented in Table 2 for the annual mean number of snow-covered cells (upper row of each cell in the table) and the end date of the snow-cover season (lower row). For the annual mean numbers of snow-covered cells, the linear trend is negative $\left(-0.3\right.$ to $\left.-0.7 \% \mathrm{a}^{-1}\right)$ at the lowest elevations $(0-500 \mathrm{~m})$ in all

Table 2. Least-squares fittings of the form $F(X)=a X+b$ for the four categories of elevation in three regions: Rocky Mountains (30-60 $\mathrm{N}$, $\left.100-140^{\circ} \mathrm{E}\right)$, Alps $\left(25-45^{\circ} \mathrm{N}, 70-110^{\circ} \mathrm{E}\right)$ and Scandinavian peninsula $\left(56-72^{\circ} \mathrm{N}, 4-30^{\circ} \mathrm{E}\right) . F(X)$ is the annual mean number of snow-covered cells (upper row of each cell) or the end date of the snow-cover season (lower row of each cell), $X$ the year number starting from 1967, a the trend, and $b$ the expected value of $F(X)$ at $X=0$ (or at the year 1966). The numbers in parentheses in upper rows represent the normalized trends defined as $a / b$

$\begin{array}{llll}\text { Elevation } & \text { Rocky Mountains } & \text { Alps } & \text { Scandinavian peninsula }\end{array}$

$\mathrm{m}$

$0-500$

500-1000

$1000-2000$

2000-4000
$-2.10 X+632.9(-0.3 \%)$

$-0.22 X+240.3$

$-6.88 X+1129.0(-0.6 \%)$

$-0.65 X+234.9$

$-3.13 X+1205.2(-0.3 \%)$

$-0.55 X+239.4$

$0.51 X+390.6(+0.1 \%)$

$-0.13 X+236.1$
$-1.10 X+167.1(-0.7 \%)$

$-0.31 X+186.1$

$+0.16 X+46.6(+0.3 \%)$

$-0.28 X+199.7$

$=+0.37 X+49.1(+0.8 \%)$

$-0.63 X+259.3$ 
the regions. At higher elevations, however, the trend is nearly zero for the Scandinavian peninsula and positive for the Rocky Mountains and the Alps. For the end date of the snow-cover season (lower row of each cell), on the other hand, the trends are negative at all the elevations in all the regions, as is the case with the Himalaya/Tibet region, implying that snow is melting earlier throughout the Northern Hemisphere (see Rikiishi and others, 2004). On comparing geographical distributions of the linear trends of the end date with those of the length of the snow-cover season (figures not presented here), we find that the decrease in length of the snow-cover season can be mostly explained by earlier snowmelt in the regions.

We now proceed to discuss possible causes of the snowcover decline. The most important finding of our study is that earlier snowmelt occurs at all the elevations in all four regions, with the largest rate on the Tibetan Plateau. The earlier snowmelt contributes more to reducing the length of the snow-cover season than the delayed snowfall. On inspecting Tables 1 and 2, we find that the snow is melting significantly earlier at higher elevations than at the lowest elevations.

It is natural to consider air-temperature rise as one of the possible causes of the earlier snowmelt. Indeed, some papers report warming trends for the Himalaya/Tibet region (Jones, 1988; Shrestha and others 1999; Liu and Chen, 2000). From the climatic point of view, physical processes of warming may be grouped into three categories: (1) global-scale warming due to the increase in greenhouse gases; (2) global-scale warming in relation to urbanization or human activities; and (3) global- or regional-scale warming associated with natural climatic change. Warming of the first kind would be observed equally at lower and higher elevations. Warming of the second kind would tend to take place at lower elevations because these are generally more densely populated and the air there is exposed to human activities such as the discharge of waste heat and the modification of the Earth's surface in terms of heat budget. Warming of the third kind would be caused by possible changes in atmospheric circulation on global or regional scales.

At the same time, we should remember that earlier snowmelt can also be caused by the decrease in albedo at the snow surface in spring and early summer, although the effect of albedo reduction has not attracted as much attention as it should. If the albedo at the snow surface is reduced, then snow will absorb more solar energy and melt away more quickly. In general, the albedo at the snow surface largely depends on the grain size of snow particles and on the impurities contained in the snowpack (Wiscombe and Warren, 1980). The grain size grows during the snowmelt season through metamorphism of snowpacks, and impurities of aerosol origin are deposited in the surface layer as dry or wet fallouts. In the snowmelt season, grain sizes continue to grow and snow impurities are concentrated at the surface layer. For these reasons, the albedo is reduced considerably in the snowmelt season (e.g. Aoki and others 2004).

Possible mechanisms for snow albedo reduction may be grouped into three categories. First, natural mineral dust from the Earth's surface (e.g. Asian dust) can significantly reduce the snow surface albedo: Warren and Wiscombe (1980) and Aoki and others (2000) have pointed out that the snow surface albedo is reduced mainly by the effect of water-dissolved solid particles in snowpacks. Aoki and others (2004) observed that the natural dust event on 11 March 2004 reduced the snow surface albedo from 0.7 to 0.5 in the Ishikari plain, Hokkaido, Japan. Naturally, mineral dust or sand dust is expected to occur more frequently in the vicinity of major deserts.

Second, air pollutants or anthropogenic aerosols originating from exhaust gases and discharged smoke are likely to reduce the snow surface albedo considerably. According to Aoki and others (1998) and Hansen and Nazarenko (2004), anthropogenic aerosols containing black carbon effectively absorb solar radiation and reduce the snow albedo significantly. In addition, Chou and others (2003) found that Asian dust deposited in snowpacks absorbs more solar radiation if it is contaminated with black carbon. Snow albedo reductions by anthropogenic aerosols may be observed more significantly in more populated regions or at lower elevations.

Third, biotic communities often form dirt layers or dust layers in ablation areas of the Himalayan glaciers in summertime (Kohshima, 1987; Kohshima and others, 1993; Takeuchi and others, 2001). The dirt layers may also reduce the albedo of glaciers and absorb more solar energy. Although this may explain the recent retreat of the Himalayan glaciers, the albedo reduction by biotic communities may only be applicable to glaciers in high mountains.

We now present an overall discussion of the possible reasons for earlier snowmelt on the Tibetan Plateau. Globalscale warming due to the increase in greenhouse gases seems unlikely to be the main cause since this would be observed equally at higher and lower elevations, whereas the decline in seasonal snow cover shows significant height dependence. Air-temperature rise due to human activities may also not be the primary reason since the Tibetan Plateau is sparsely inhabited and very far from megalopolises and industrial areas. Albedo reduction through biological activities in summertime may not be applicable either, since snow accumulation is not usually observed in summertime on the Tibetan Plateau.

On the other hand, Asian dust originating from the surrounding deserts seems to reduce snow surface albedo and accelerate snowmelt, because the Tibetan Plateau lies in the midst of semi-arid regions and is surrounded by extensive deserts including the Taklimakan, Gobi and Kazakhstan/Uzbekistan deserts. Earlier snowmelt may in turn help spring winds to stir up more sand dust, which may result in further earlier snowmelt. This kind of positive feedback process from the albedo reduction is likely to contribute to desertification in the semi-arid region. At the same time, we should pay attention to the increase in anthropogenic aerosols in recent years, because fallout of aerosols at the snow surface may also significantly reduce the albedo, causing earlier snowmelt. Lower elevations are more densely populated and more exposed to aerosols of human origin and discharges of waste heat than higher elevations. Accordingly, the global decline of seasonal snow cover at lowest elevations is likely to be caused by environmental changes resulting from human activities.

In any case, we should pay much more attention to the role of albedo reduction in the global decline of seasonal snow surface. Further studies are crucial to test the abovementioned scenario of positive feedback between earlier snowmelt and desertification. 


\section{ACKNOWLEDGEMENTS}

We thank the staff of the NSIDC who made it possible for us to analyze this important dataset of the Northern Hemisphere EASE-Grid Weekly Snow Cover and Sea-Ice Extent. Helpful comments from E. Mosley-Thompson (co-chief editor), Jiawen Ren (scientific editor), R. Armstrong and $\mathrm{H}$. Brecher and critical reading by an anonymous reviewer are greatly appreciated. Sincere thanks are extended to E. Mosley-Thompson and $\mathrm{H}$. Brecher for editing the text.

\section{REFERENCES}

Aoki, T. and 6 others. 1998. Spectral albedo observations on the snow field at Barrow, Alaska. Polar Meteorol. Glaciol., 12, 1-9.

Aoki, T., T. Aoki, M. Fukabori, A. Hachikubo, Y. Tachibana and F. Nishio. 2000. Effects of snow physical parameters on spectral albedo and bidirectional reflectance of snow surface. J. Geophys. Res., 105(D8), 10,219-10,236.

Aoki, T. and 12 others. 2004. Effect of atmospheric aerosol deposition on snow albedo reduction. In Proceedings of the 5th International Workshop on Global Change: Connection to the Arctic (GCCA5). Fairbanks, AK, International Arctic Research Center, 147-150.

Armstrong, R.L. and M.J. Brodzik. 2002. Northern Hemisphere EASE-Grid Weekly Snow Cover and Sea Ice Extent, Version 2. Boulder, CO, National Snow and Ice Data Center.

Chou, C.C.-K., T.-K. Chen, S.-H. Huang and S.C. Liu. 2003. Radiative absorption capability of Asian dust with black carbon contamination. Geophys. Res. Lett., 30(12), 1616. (10.1029/ 2003GL017076.)

Fujita, K., M. Nakawo, Y. Fujii and P. Paudyal. 1997. Change in glaciers in Hidden Valley, Mukut Himal, Nepal Himalaya, from 1974 to 1994. J. Glaciol., 43(145), 583-588.

Hansen, J.E. and L. Nazarenko. 2004. Soot climate forcing via snow and ice albedos. Proc. Natl. Acad. Sci. USA (PNAS), 101(2), 423-428.

Jones, P.D. 1988. Hemispheric surface air temperature variations: recent trends and an update to 1987. J. Climate, 1(6), 654-660.

Kadota, T., K. Fujita, K. Seko, R.B. Kayastha and Y. Ageta. 1997. Monitoring and prediction of shrinkage of a small glacier in the Nepal Himalaya. Ann. Glaciol., 24, 90-94.

Kohshima, S. 1984. Living micro-plants in the dirt layer dust of Yala Glacier, Nepal Himalaya. Bull. Glacier Res., 2, 91-97.
Kohshima, S. 1987. Formation of dirt layers and surface dust by micro-plant growth in Yala (Dakpatsen) Glacier, Nepal Himalaya. Bull. Glacier Res., 5, 63-68.

Kohshima, S., K. Seko, and Y. Yoshimura. 1993. Biotic acceleration of glacier melting in Yala Glacier, Langtang region, Nepal Himalaya. IAHS Publ. 218 (Symposium at Kathmandu 1992 Snow and Glacier Hydrology), 309-316.

Liu, X. and B. Chen. 2000. Climatic warming in the Tibetan Plateau during recent decades. Int. J. Climatol., 20(14), 1729-1742.

Nakawo, M. 2001. The conception and the outline of the Cryosphere Research Expedition in the Himalaya. Seppyo, J. Jpn. Soc. Snow Ice, 63(2), 139-146. [In Japanese.]

Rikiishi, K., E. Hashiya and M. Imai. 2004. Linear trends of the length of snow cover season in the Northern Hemisphere as observed by the satellites in the period 1972-2000. Ann. Glaciol., 38, 229-237.

Robinson, D.A., K.F. Dewey and R.R. Heim, Jr. 1993. Global snow cover monitoring: an update. Bull. Am. Meteorol. Soc., 74(9), 1689-1696.

Shrestha, A.B., C.P. Wake, P.A. Mayewski and J.E. Dibb. 1999. Maximum temperature trends in the Himalaya and its vicinity: an analysis based on temperature records from Nepal for the period 1971-1994. J. Climate, 12(9), 2775-2786.

Takeuchi, N., S. Kohshima and K. Seko. 2001. Structure, formation, and darkening process of albedo-reducing material (cryoconite) on a Himalayan glacier: a granular algal mat growing on the glacier. Arct. Antarct. Alp. Res., 33(2), 115-122.

Warren, S.G. and W.J. Wiscombe. 1980. A model for the spectral albedo of snow. II. Snow containing atmospheric aerosols. J. Atmos. Sci., 37(12), 2734-2745.

Wiscombe, W.J. and S.G. Warren. 1980. A model for the spectral albedo of snow. I. Pure snow. J. Atmos. Sci., 37(12), 2712-2733.

Yasunari, T., A. Kitoh and T. Tokioka. 1991. Local and remote responses to excessive snow mass over Eurasia appearing in the northern spring and summer climate - a study with the MRIGCM. J. Meteorol. Soc. Jpn, 69, 473-487.

Zhang, Y.L.T. and B. Wang. 2004. Decadal change of the spring snow depth over the Tibetan Plateau: the associated circulation and Influence on the East Asian summer monsoon. J. Climate, 17(14), 2780-2793.

Zhao, H. and G.W.K. Moore. 2004. On the relationship between Tibetan snow cover, the Tibetan plateau monsoon and the Indian summer monsoon. Geophys. Res. Lett., 31(14), L14204. (10.1029/2004GL020040.) 